\title{
Engineering Design Process of Arduino Uno-based Smart Classroom Technology
}

\author{
Deny Nusyirwan ${ }^{1, *}$, Eko Prayetno ${ }^{1}$, Sumantri ${ }^{2}$, and Prasetya Perwira Putra Perdana ${ }^{2}$ \\ ${ }^{1}$ Department of Naval Engineering, Faculty of Engineering, Universitas Maritim Raja Ali Haji, Jalan Politeknik Km. 24 \\ Kelurahan Senggarang, Kecamatan Tanjungpinang Kota, Kota Tanjungpinang 29115, Provins Kelupauan Riau, Indonesia \\ ${ }^{2}$ Department of Electrical Engineering, Faculty of Engineering, Universitas Maritim Raja Ali Haji, Jalan Politeknik Km. 24 \\ Kelurahan Senggarang, Kecamatan Tanjungpinang Kota, Kota Tanjungpinang 29115, Provins Kelupauan Riau, Indonesia
}

*Corresponding Author: denynusyirwan@umrah.ac.id

Article history

Received: 17.07.2020

Revised: 18.09 .2020

Accepted: 28.09.2020

DOI:10.31629/jit.v1i2.3169

\begin{abstract}
The important role of higher education in the $21^{\text {st }}$ century is to participate in educating the public through the development of research results, therefore the Department of Electrical Engineering at the Raja Ali Haji Maritime University emphasizes the importance of implementing an engineering design process to be able to produce technology-based innovations needed by society. This research is a form of higher education contribution in improving student learning outcomes in elementary schools, through the provision of facilities in classrooms. Technology in schools is one of the driving forces for advancing education in schools and is expected to be able to change the mindset of students at Government Primary School (SD Negeri) 011 Tanjungpinang Timur to get to know technology more. It can be said that to realize the perfection of students, in addition to learning activities, supporting facilities are also needed at school according to technological developments. It is hoped that the facilities in technology-based schools will be able to encourage students to be more enthusiastic about learning, have a desire to know developments in the world of technology and change their mindset towards the use of technology in everyday life. From the observations, it was found that the main problem was the minimal use of technology in schools. With these technological problems, this study will design technology-based prototypes, namely smart classrooms based on Arduino Uno, with the aim of making it easier for teachers to turn on electrical equipment in class without direct contact with switches. The intelligent classroom system design uses the Arduino uno as a controller, the HC-06 bluetooth module as a liaison for the user's android with the Arduino Uno, and the boarduino application as a command from the android via bluetooth transmission media.
\end{abstract}

Keywords: smart classroom, Arduino-Uno, Bluetooth, learning outcomes

\section{Introduction}

Education is an effort to create an atmosphere of learning and the learning process so that students actively develop their potential to have religious spiritual strength, self-control, personality, intelligence, noble character, and skills needed by themselves, society, the nation 
and the State [1]. School is an institution with a well-organized organization and all its activities are deliberately planned which is called the curriculum [2].

School education is education that is deliberately designed and implemented with strict rules, such as having to be tiered and sustainable so it is called formal education [3]. In essence, the relationship between education and school can be seen in the definition of education above that guidance, development and self-control are part of the educational process that has been previously planned and regulated with the aim of realizing the perfection of the development of students. It can be said that to realize the perfection of students, the quality of education and supporting facilities in schools are needed according to technological developments. Technological developments in schools make students more aware of developments in the world of technology and change the mindset of students to develop existing technology.

The research process and data search were carried out through observation at an educational institution SDN 011 Tanjungpinang Timur. Problems found when observations are made at these locations include uncomfortable classrooms, simple technology, and electronic equipment in the classroom is left on when the learning process is complete. From the many problems that exist in this school, the main problem is determined, namely technology in schools. From the main problems that were found, some ideas or concepts emerged to minimize this problem. For some of these ideas or concepts, one idea or concept to be designed is determined, namely the Design of Smart Classroom Systems Based on Arduino Uno.

\section{Literature Review}

\subsection{Previous research}

In a previous study entitled "Smart Home Automatic Using Bluetooth Media Based on Atmega 328 Microcontroller" conducted by Ageng Setiani Rafika where the research designed a smart home system using Bluetooth communication media and Atmega 328 microcontroller which functions to process input data from users who will provide conditions. on or off on electronic devices which include lights, fans and open and close doors or candles. Giving orders is done by using a Bluetooth application which input some codes as an on or off command, for example the code "A" the door is open "B" the door is closed [4].

In another study entitled "Smart Home Automation with Raspberry $\mathrm{Pi}$ and Android Smartphone" conducted by Erick Fernando where the research designed a smart home system using wireless communication media using $\mathrm{Wi}-\mathrm{Fi}$ and a Raspberry Pi microcontroller as controllers and data processing from users who will provide command on or off to lamp [5].

In the previous study, it has been designed a home control system using Android and using Bluetooth as the transmission medium. In this study, Android will control electronic equipment in the house. This study uses a light sensor to ensure the light is actually on and a timer to find out how long electronic equipment is used [6].

Also, other research entitled has successfully designed a system that could run Electric Otoped. This movement is in the form of forward, backward and turning of the Electric Otoped automatically using Bluetooth on the android as a communication medium [7].

This study aims to design a technology-based prototypes for smart classrooms based on Arduino Uno system. The program aims to prepare a tools for teachers to turn on electrical equipment in class without direct contact with switches.

\subsection{Theoretical basis}

The working system of this tool is that when the keystroke command is entered into the boarduino application, this application will send commands to Arduino using a Bluetooth network that is connected to each other between the existing Bluetooth on the user's android with the HC-06 Bluetooth module. This HC-06 Bluetooth module will later send a signal to Arduino uno to provide voltage to each LED line according to the command. With the provision of voltage on the LED line to be turned on, the LED will turn on automatically. LED 1 will light up if Arduino provides voltage to pin 2, LED 2 will light up if Arduino provides voltage to pin 3, LED 3 will light up if Arduino provides voltage to pin 4, LED 4 will light up if Arduino provides voltage to pin 5, all LEDs will turn on if Arduino simultaneously provides voltage to all pins, and the LED will turn off if Arduino disconnects the voltage on all pins. Please see Figure 1. 


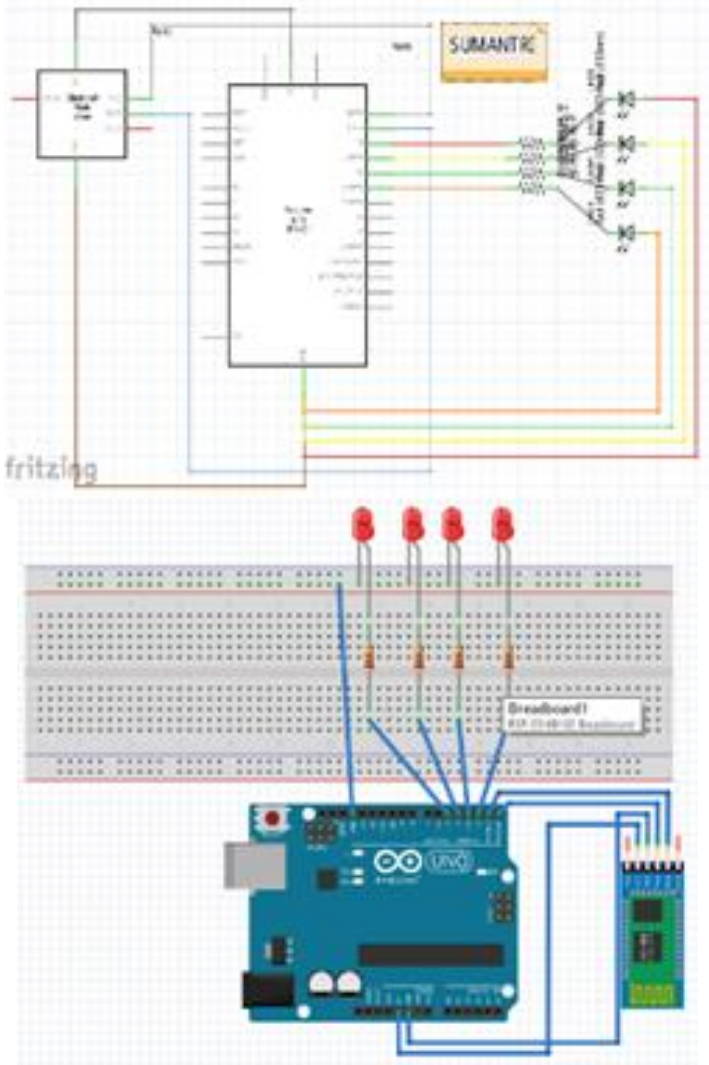

Figure 1. Smart Classroom System based on Arduino Uno

\section{Engineering Design Process}

The engineering design process in designing intelligent classrooms applies the twin gem approach at the beginning of the process, namely the process of finding problems and the process of determining problems. This approach has been introduced by the British Design Council. Please see Figure 2. [8] After going through the solution determination stage, it can be continued to the prototype stage and usability testing.

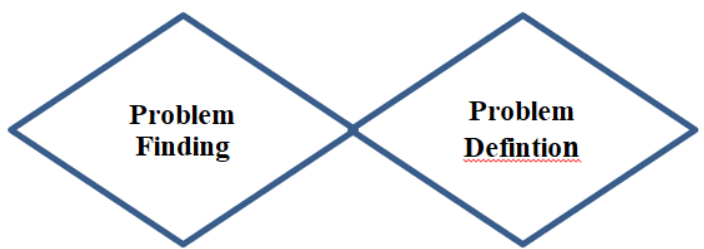

Figure 2. Engineering Design Process introduced by the British Design Council

\subsection{Etnographic}

Government Primary School (SD Negeri) 011 Tanjungpinang Timur has several classrooms consisting of 2 floors. This school has sports facilities such as a badminton court and a volleyball court to develop the talents of students at the school. Please see Figure 3. Government Primary School (SD Negeri) 011 Tanjungpinang Timur is one of the primary schools located in the Tanjungpinang Timur district. From the observations, it was found that the school still has several technologies that are operated manually, such as the system for opening and closing class doors with the help of human power, student attendance, and some classrooms still use fans to cool the class, which is still pressing a button.

In this study, the school being studied knew about the existence of researchers, but the researchers did not participate in carrying out activities and activities in the group being studied [9].

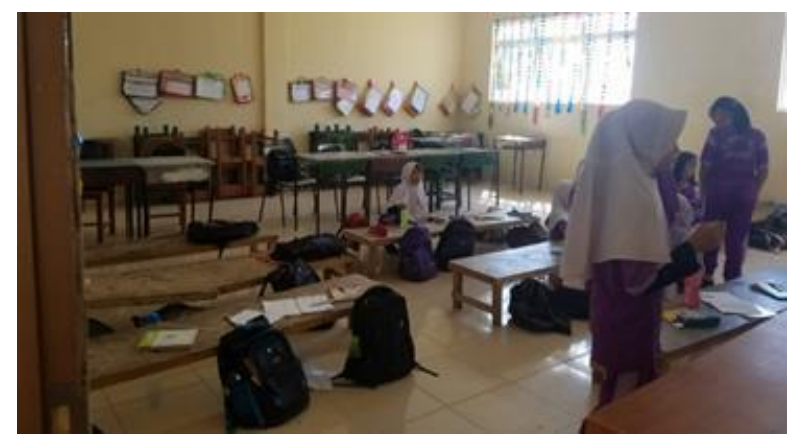

Figure 3. Gov. Primary School 011 Tanjungpinang Timur

\subsection{Brainstorming Problems}

The ethnographic process carried out at Government Primary School (SD Negeri) 011 Tanjungpinang Timur has found several problems ranging from the technology used is still manual, electronic equipment that is left on even though the classroom is no longer used due to negligence from the school, electronic equipment left unrepaired, garbage scattered, the arrangement of books scattered in the library, and the library that is not equipped with supporting facilities such as tables and chairs. Figure 4. shows the problems found in schools through the process of brainstorming ideas.

The rules in brainstorming ideas are avoiding direct judgment and refuting the idea being conveyed., Encouraging extraordinary / strange ideas, thinking like a child where there is no fear of mistakes., Prioritizing quantity over quality, maintaining all talks and discussions and ideas 
conveyed remain on topic and no one talks simultaneously [10].

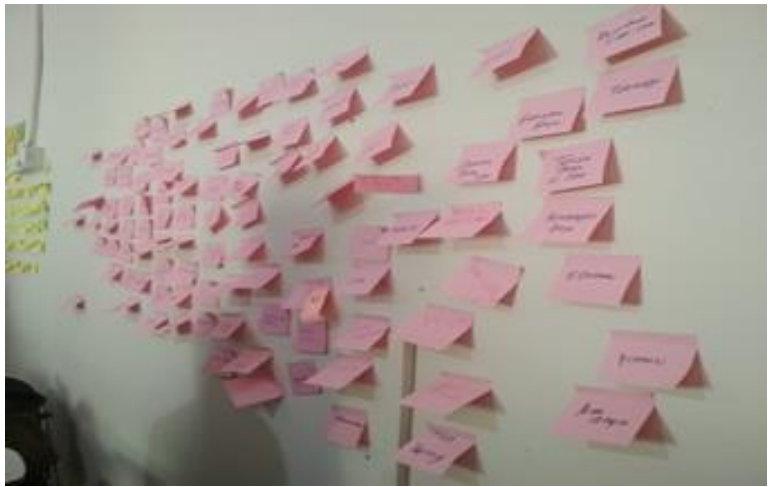

Figure 4. Brainstorming Problems

\subsection{Main Problem Definition}

The problems found in this research location require the researcher to choose one of the problems that will create concepts and ideas in dealing with this problem. The main problem that is taken in determining the design concept is regarding technology development in school.

\subsection{Solution Definition}

In the presentation of the main problem that is taken, some concepts and ideas are determined. These concepts and ideas are expected to be able to address the main problems that occur at Government Primary School (SD Negeri) 011 Tanjungpinang Timur. Regarding this, there are several concepts and ideas that were conveyed to the school, namely automatic school gates, teacher and student attendance systems using RFID, book layout systems using RFID, automatic trash cans using ultrasonic sensors, and classroom systems. smart based Arduino uno. The concepts and ideas taken to be developed at Government Primary School (SD Negeri) 011 Tanjungpinang Timur are the design of a smart classroom system based on Arduino uno.

\subsection{Skething}

From the concepts and ideas that will be developed at Government Primary School (SD Negeri) 011 Tanjungpinang Timur, a sketch of the design is made using paper. In sketching, it is not explained in detail about the work system of the design but explains in a concise and easy to understand manner about this design. Please see Figure 5.

The design sketches do not draw something that already exists, for example pictures of figures, pictures of living things and the like. Instead, the designer is involved in the process of trying to provide an external definition to something that imagined [11].

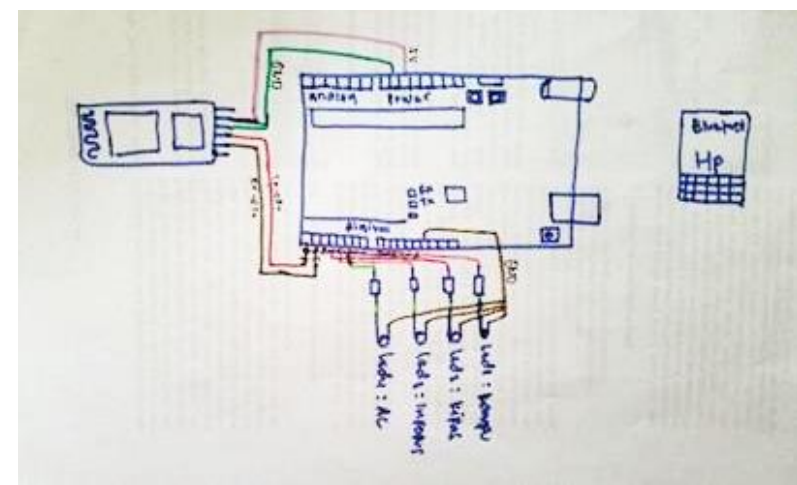

Figure 5. Sketching

\section{Results}

\subsection{Low Resolution Prototype}

The simple prototype of designing a smart classroom system based on the Arduino uno still uses plasticine in the manufacturing process. This plasticine is made to resemble several components, namely the Arduino Uno as a controller, the HC-06 Bluetooth module, and Bluetooth on Android as a medium for transmitting commands (Figure 6).

The prototype creation stage is a stage in the Engineering Design Process which has begun to require financing. Therefore, at this stage, the designer will start making an economical and flexible prototype, with the intention that design changes can be carried out easily and will not require large financing. Paper prototyping will allow a User Centered Design (UCD) approach before other engineering approaches are initiated [12]. Prototypes in this stage are known as a low-resolution one [13].

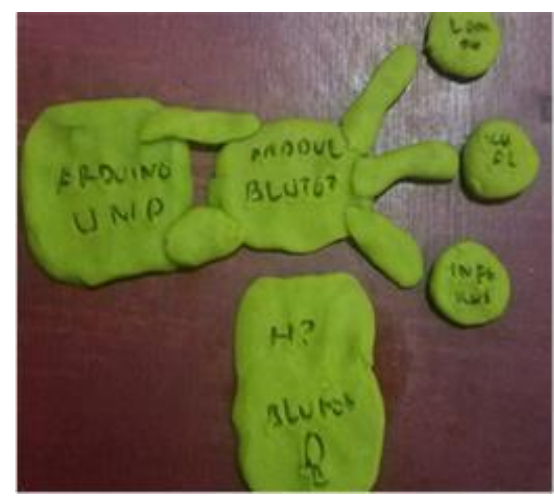

Figure 6. Low Resolution in plasticine Prototype 


\subsection{Virtual Prototype}

At the stage of making this virtual prototype using the Autodesk Inventor application. Please see Figure 7. Designers use virtual models to replace real prototypes and analyze them using various types of simulations which aim to recreate the real-life conditions in which the product needs to operate.

This process is aided by modern computer programs, designed to assist modern engineers in their work. The virtual model is made to reflect the real image, or as close to real as possible [14]. The main advantage of virtual prototyping is that prototyping of the innovation concept for initial testing is not required because any adjustments will be made directly in virtual reality using simulation.

The prototypes can be explored virtually and interactively, then they can be studied and simulated before implementation in the real world [15].

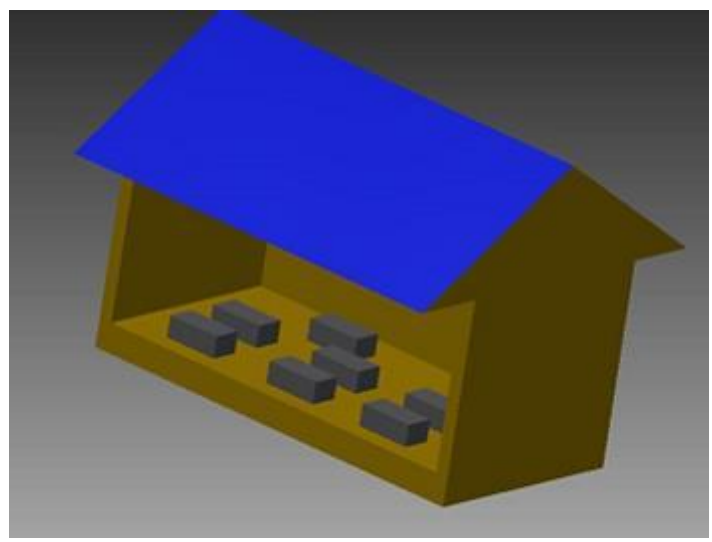

Figure 7. Virtual Prototype

\subsection{Electrical Integrated Prototype}

The assembly of electronic components and the use of programming languages has started. To be able to better understand the characteristics and make necessary changes from problems that are not found in plasticine prototypes and virtual prototypes.

Figure 8 shows the integration of electronic circuits with supporting materials from a smart classroom to help get a better prototype before being displayed to the user.
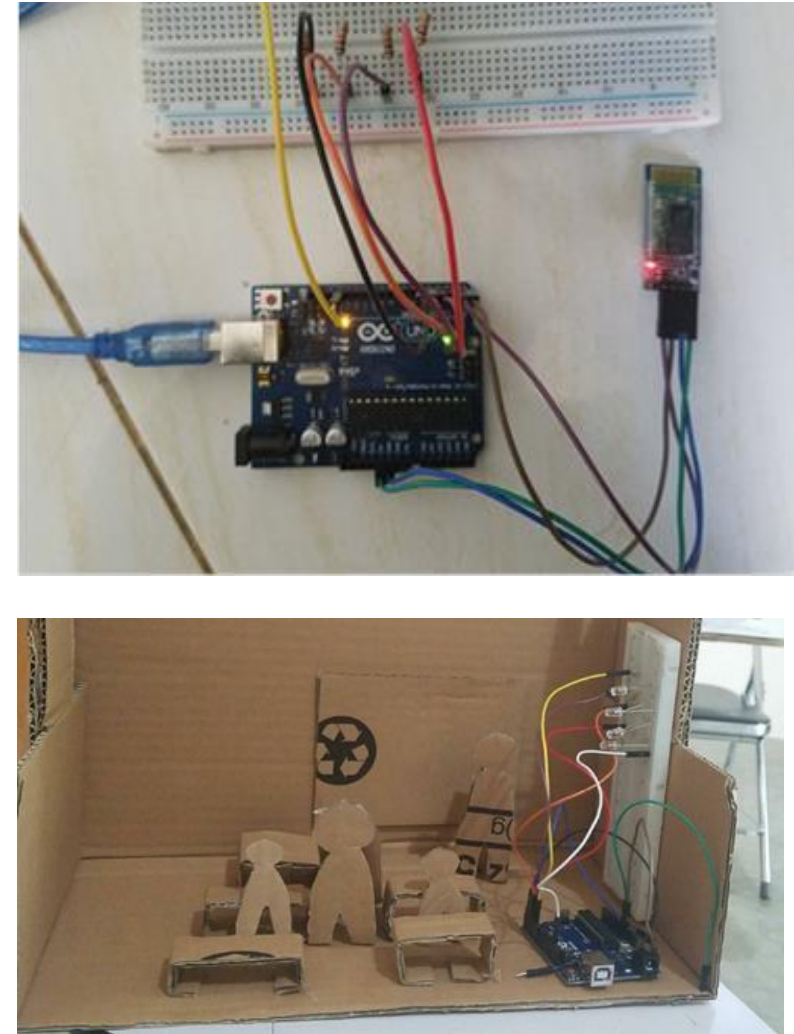

Figure 8. Electrical Integrated Prototype

\subsection{User Testing}

The usability testing stage is carried out after the design stage is complete. This usability test is carried out through presentations in front of users, as shown in Figure 9.

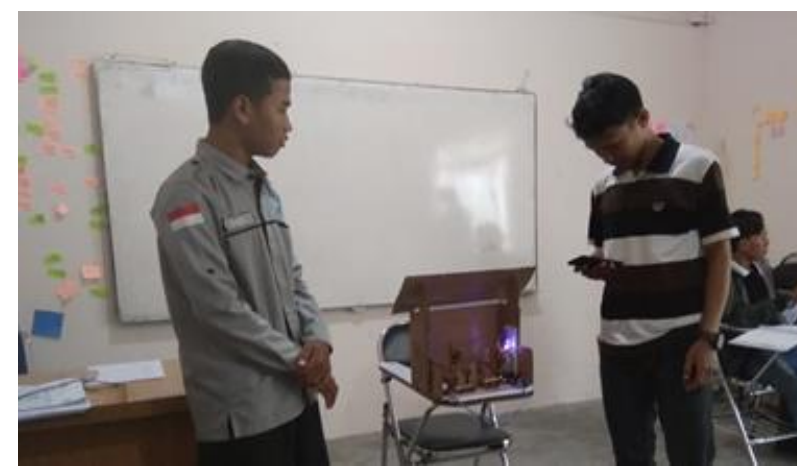

Figure 9. Demonstration of the use of prototypes among fellow research members to obtain input prior to testing for potential users

Users are the people who will use this system design. Users (users) in designing this system are teachers who teach in the class. Please see Figure 10. After the design flaws have been identified, 
design recommendations are proposed to improve the ergonomic quality of the product [16].

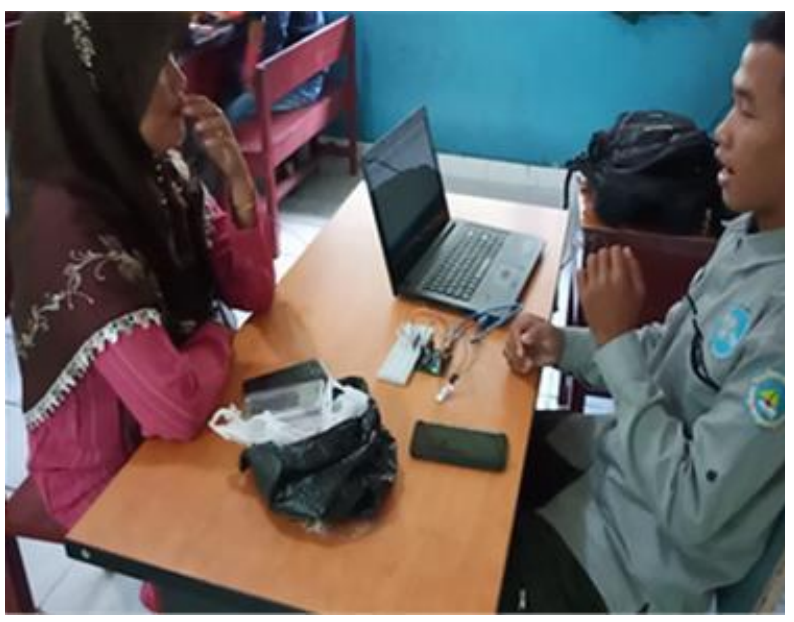

Figure 10. Pilot Testing Of Potential Users

\subsection{User Experience}

At the user experience stage, user feedback is obtained after trying to use this system design. This feedback will later be used as a benchmark in the development of smart classroom system design based on the Arduino uni to make it easier to use. Technology-based innovators are very aware that the success of innovation results is not only seen from the benefits of the product to be produced but also needs to pay attention to the user experience factor. Product development is no longer just about implementing features and testing usability, but also about designing products that are fun and support basic human needs and values. Thus, the user experience in the EDP stage should be a major concern of product development [17]

User Experience (UX) will broaden the view of product interactions with users from an emotional aspect. UX's motivation is to develop positive experiences and emotions. Therefore, the product must meet the psychological needs and motives of the customer [18].

\section{Conclusion}

The main problem at Government Primary School (SD Negeri) 011 Tanjungpinang Timur is the lack of application of technology in schools, therefore a smart classroom system based on Arduino Uno was designed to help smooth the learning process of students in the classroom. This design uses the Arduino uno as a controller, the HC06 Bluetooth module for data transmission media and Bluetooth on the user's android to give commands to Arduino via Bluetooth transmission media. Based on the results of interviews, this technology has received positive input, apart from low-cost technology. The use of Android-based smart phones is also well known, so that in its realization, it is hoped that potential users will not experience difficulties. The design of a smart classroom system based on Arduino Uno may motivate students to initiate a technology and improve the teacher efficiency in teaching and learning. For the further move, an effort and program from the government is needed to encourage technology to enter school, that collaborate with local universities in a community service programs.

\section{References}

[1] UU No 20 Tahun 2003 tentang Sistem Pendidikan Nasional

[2] Ahmadi, A. dan Uhbiyati, N., Ilmu Pendidikan, Rineka cipta, Jakarta, 1991, hlm 162

[3] Raharja, U. T., dan La Sula, Pengantar Pendidikan, Rineka Cipta, jakarta, 1998, hlm. 164

[4] Rafika, A., S., Putra, M., S., H., dan Larasati, W., "Smart Home Automatic Menggunakan Media Bluetooth Berbasis Mikrokontroller Atmega 328", CCIT Jurnal, Vol.8, No. 3, 2015

[5] Fernando, E., "Automatisasi Smart Home Dengan Raspberry Pi Dan Smartphone Android", Konferensi Nasional Ilmu Komputer (KONIK), 2014

[6] Sadewo, A., D., B., Widasari, E., E., Muttaqin, A., "Perancangan Pengendali Rumah menggunakan Smartphone Android dengan Konektivitas Bluetooth", Jurnal Pengembangan Teknologi Informasi dan Ilmu Komputer, Vol. 1, No. 5, 2017

[7] Fandriansyah,A., H., Dirgantoro, B., dan Osmond, A., B., "Aplikasi Kontrol Dan Monitoring Pada Otopad Elektrik Via Bluetooth Berbasis Android", e-Proceeding of Engineering : Vol.4, No.1, hal 858,2017

[8] Strategie \& User experience designer [Daring], Tersedia pada : https://www.ivobosma.nl/ , [ Diakses : 25 April 2019 ]

[9] Wagner, C., Kawulich, B., dan Garner, M., "Collecting Data Through Observation", Doing Social Research: A global context, McGraw Hill, 2012

[10] Nusyirwan, D., "Design Thinking sebagai Bridge of Innovation Perguruan Tinggi dan Industri di Jurusan Teknik Elektro Universitas Maritim Raja 
Ali Haji (UMRAH)", Jurnal Sustainable Vol. 07, No. 02, hal. 86-94, 2018

[11] Tovey, M., Porter, S., dan Newman, R., " Sketching, concept development and automotive design", Design Studies Volume 24, Edisi 2, hal 135-153, Elsevier 2003

[12] Zhang, T., Rau, P., P., Salvendy, G., dan J. Zhou. "Comparing Low and High-Fidelity Prototypes in Mobile Phone Evaluation", International Journal of Technology Diffusion, 3(4), IGI Global, 2012

[13] Nusyirwan, D., Engineering Design Process Engineering Student Centered Experience Learning (ESCEL) di Jurusan Teknik Elektro Universitas Maritim Raja Ali Haji (UMRAH), Jurnal Sustainable Vol. 06, No. 01, hal. 24-35, 2017

[14] Łukaszewicz, K., "Use of CAD Software in the Process of Virtual Prototyping of Machinery", 7th International Conference on Engineering, Project, and Production Management, Procedia Engineering 182 hal 425 - 433, Elsevier Ltd. 2017
[15] Wang, E., "Interactive virtual prototyping of a mechanical system considering the environment effect. Part 2: Simulation quality", Comptes Rendus Mécanique Volume 339, Edisi 9 hal 605615, Elsevier Masson SAS, 2011

[16] Bastien, J., M., C., "Usability testing: a review of some methodological and technical aspects of the method", International Journal of Medical Informatics, Volume 79, Edisi 4 hal e18-e23, Elsevier Ireland Ltd, 2010

[17] Johnson, G., I., Clegg, C/.W., dan Ravden, S., J., "Towards Practical User Experience Evaluation Methods", Applied Ergonomics Volume 20, Edisi 4, Pages 255-260, Elsevier Ltd, 1989

[18] von Saucken, C., Lachner, F., dan Lindemann, U., "Principles for User Experience What We Can Learn from Bad Examples", International Conference on Kansei Engineering \& Emotion Research, June 2014. 